\title{
SUSTAINABILITY FAILURE: SOME CAUSES OF INACTION
}

\section{KUDARCOS FENNTARTHATÓSÁG: A TÉTLENSÉG NÉHÁNY OKA}

\author{
Lengyel Attila ${ }^{1}$
}

Turizmus Vendéglátás Tanszék, Gazdálkodási Kar, Neumann János Egyetem, Magyarország

\author{
Keywords: \\ sustainability inaction \\ socio-ecological crisis \\ psychological mechanisms \\ materialistic values \\ eudemonic values \\ Kulcsszavak: \\ fenntarthatósággal kapcsolatos tétlenség \\ szocio-ökológiai válság \\ pszichológiai mechanizmusok \\ materialista értékek \\ eudemonikus értékek
}

\begin{abstract}
While the question of sustainability has received more and more attention and publicity in the past decades, all ecosystems services has been constantly deteriorating during the same period. There is an abyss between theory and rhetoric and meaningful and effective action. Our present-day socio-ecological crisis is the result of a distorted world view which in turn is caused by deep psychological mechanisms affecting the individual and the society. Recognizing these underlying mechanisms, making people aware of how they work might help change the suicidal course that the developed societies based on free market capitalism, neoliberal ideology and excessive consumerism has been on in the last two hundred years. This paper aims to discuss some of the obstacles that seem to have been hindering effective action.

Összefoglalás

Miközben a fenntarthatóság egyre nagyobb figyelmet és publicitást kapott az elmúlt évtizedekben, ugyanezen időszak alatt minden ökoszisztéma szolgáltatás folyamatosan romlott. Hatalmas szakadék van az elmélet és retorika valamint az értelmes és hatékony cselekvés között. A jelenkori szocio-ökológiai válság egy torz világkép eredménye, melyet az egyénre és a társadalomra ható mély pszichológiai mechanizmusok formálnak. Ezeknek a mögöttes mechanizmusoknak a felismerése és az emberekben való tudatosítása segíthet letérni arról az öngyilkos útról, amin a szabad-piaci kapitalizmusra, neoliberális ideológiára és mértéktelen konszumerizmusra berendezkedő nyugati társadalmak járnak már kétszáz éve. Jelen írás néhány olyan akadályt elemez, mely láthatóan hátráltatja a hatékony cselekvést.
\end{abstract}

\section{Introduction}

Few years ago, a prominent ecologist and university lecturer asked the following question: „How is it possible that virtually nothing is done to avoid a catastrophe which is known by everybody and is approaching unstoppably?” (Original: „Hogyan lehetséges az, hogy

\footnotetext{
1 Dr. Lengyel Attila Tel.: +36 56510300

E-mail cím: lengyel.attila@gk.uni-neumann.hu
} 
egy mindenki által ismert, feltartóztathatatlanul közeledő katasztrófa elhárítása érdekében gyakorlatilag semmi sem történik?” [28:823]. Inaction may seem even more enigmatic in the light of a study published by Nature in which $70 \%$ of respondents were aware of the expected consequences of climate change [38]. Research in psychology, sociology, social psychology, eco-psychology, historical sociology, economic sociology, and other disciplines explains why the individual and human communities do not want or are able to change in the direction of averting an impending disaster. Creeping normalcy, suppression, lack of trust, mass psychosis, system inertia (status quo), dread management theory, Khazoom-Brooks postulate (backward effect), religious belief, lack of interconnection with nature, or time and spatial discounting of problems, responsibility and values are some of the possible and often complementary explanations. In what follows some of these underlying psychological mechanisms will be discussed to direct attention to their central importance in the failing sustainability efforts.

\section{Some causes of inaction}

\subsection{Creeping normalcy}

In Diamond's formulation it is "slow trends hidden behind noisy extremes"[7: 435]. Although the coining of the term "creeping normalcy" can be attributed to Diamond, the phenomenon itself has already been described by many before. Milbrath says about "creeping environmental problems", "Societies have considerable difficulty seeing incremental changes like growth in their population. However, these changes accumulate exponentially over time, adding up to a major environmental degradation. Societies conducting business-as-usual readily allow the destruction of entire ecosystems, seemingly without being aware it is happening. When decision makers finally recognize the problem, it may already be a crisis with irretrievable loss already suffered.” [35:114]. These slow changes are misleading as they create the illusion that the process will always be incremental. In connection with climate change [7] points out that the noise of extreme weather events (fluctuations), which are increasingly common as a disruptive phenomenon, disguises the slight annual change in temperature.

\subsection{Information overload}

As early as 1962, Meier in his work titled The Communications Theory of Urban Growth, predicted that information overload could become a dangerous problem in an increasingly congested urbanized environment [34]. His prediction was confirmed. Information overload of the information age brought about several psychological problems. Information Anxiety [36] or Paradox of Choice $[1,19]$ is the consequences of "excessive urbanization" of the human mind. Information overload reduces psychological well-being, productivity, innovation, and decision-making ability [17]. Consumption patterns of consumer societies are noticeable in connection with information. In addition to the information anxiety, information dependence, as a form of addiction, is also characteristic of modern life. It is primarily connected with excessive internet use [5]. In the ocean of information important and valuable information become inflated or even lost. Milbrath warns, "No matter how profound the thought or how urgent the appeal, any high priority message is likely to get smothered in a constant barrage of banal messages. Hordes of change agents, each crying 'follow me', peddle their messages to whomever will listen. How can we think together, learn together, and make democracy function in a blizzard of messages? The learning that we all need to undertake in order to transform modem society to a sustainable society is enormously impeded by info glut." [35:109].

\subsection{Denial}

In contrast to conscious denial the involuntary form is defined by Vaillant as: “.... involuntary mental mechanisms that distort our perception of internal and external reality to reduce subjective distress." [39:89]. Of course, the deliberate and organized form of denial, such as denial of climate change, is also important [9]. It is an involuntary, subconscious mechanism, which is activated even in the face of known catastrophic consequences [7]. Diamond mentions a survey among people living near valley dams. The fear of the dam braking 
is small among people living far from the dam. This is not surprising. However, when approaching the dam a few kilometres close, the fear of the dam breaking drops back to practically zero level. This is a typical example of keeping overly fearful events pushed back in the subconscious. Figure 1. shows trends for environmental issues spanning almost sixty years of change.
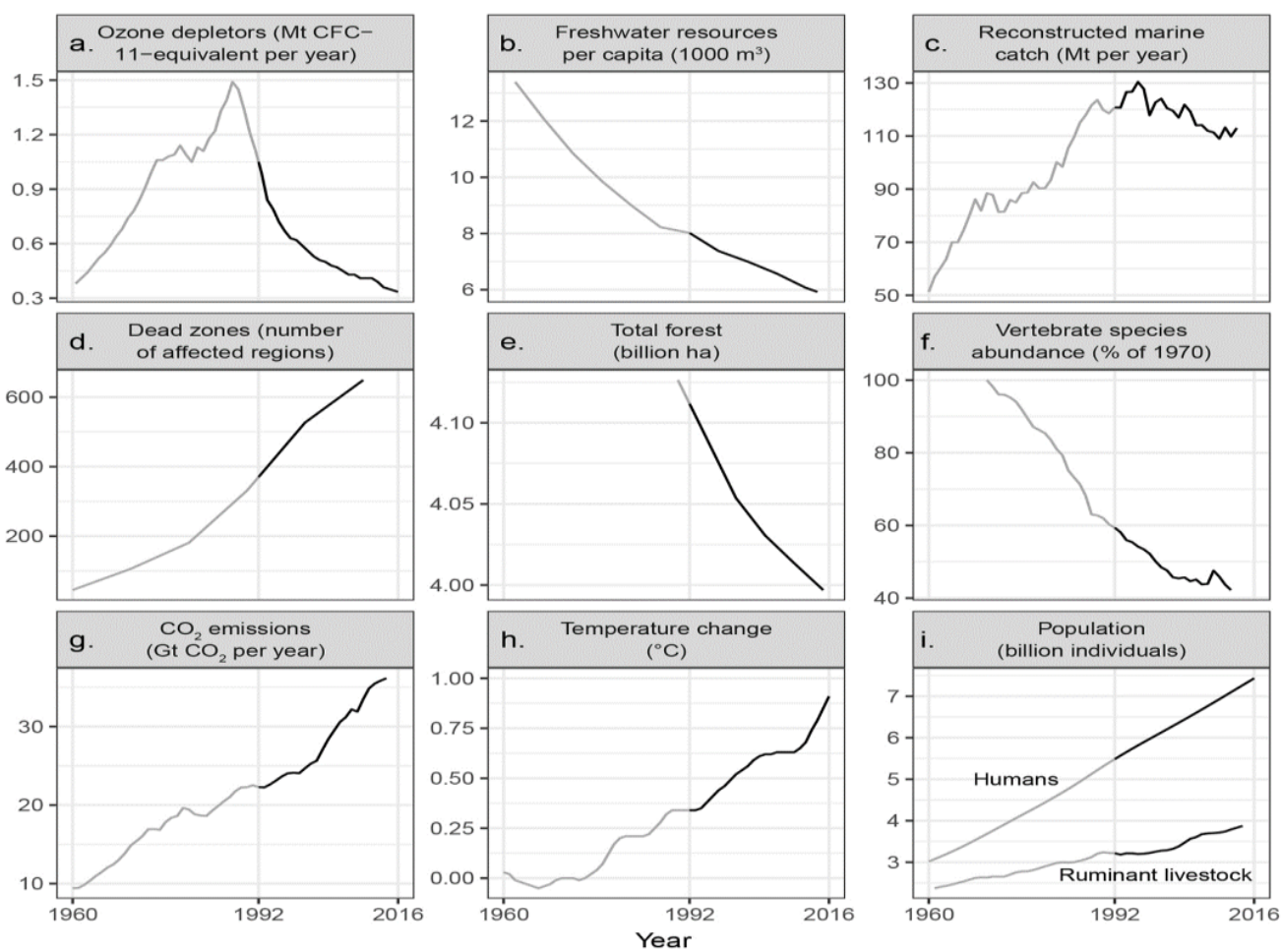

Figure 1 Trends over time for environmental issues

Source: Ripple et al. 2017

As all issues have been sharply and steadily worsening, one might interpret the present situation as 'mission impossible' and use the same kind of defence mechanisms as people living in close proximity of valley dams, that is, push the whole unsolvable and catastrophic problem into the subconscious.

In another study, [29] examined a sample of $n=364$, consisting of middle-aged (40) or older (72\%), mostly graduates (83\%), with above-average earnings (90\%). The relative frequency of responses is depicted in Figure 2.

Within the category 'other' $80 \%$ of respondents gave answers such as 'we', 'we together', 'the people'. All in all, only one fifth of the sample (28\%) think that solving the world's problems is primarily a matter of personal responsibility and $72 \%$ of the sample is waiting for the solution from somebody else. While the issue of 'responsibility' does not appear in the answer options and for the problems of mankind, the 'other' category gave the respondent the opportunity to formulate ideas about individual responsibility. $72 \%$ of respondents seem to have been moved by subconscious denial mechanisms. Protection of positive self-image [6] might be the reason for that. If one declares one's personal responsibility, it entails that one has to acknowledge what one is doing, or rather not doing in order to alleviate problems. It is in fact the cognitive dissonance investigated by [12] and the involuntary denial mechanism used to avoid it. This has also been proven in connection with climate change [30]. 


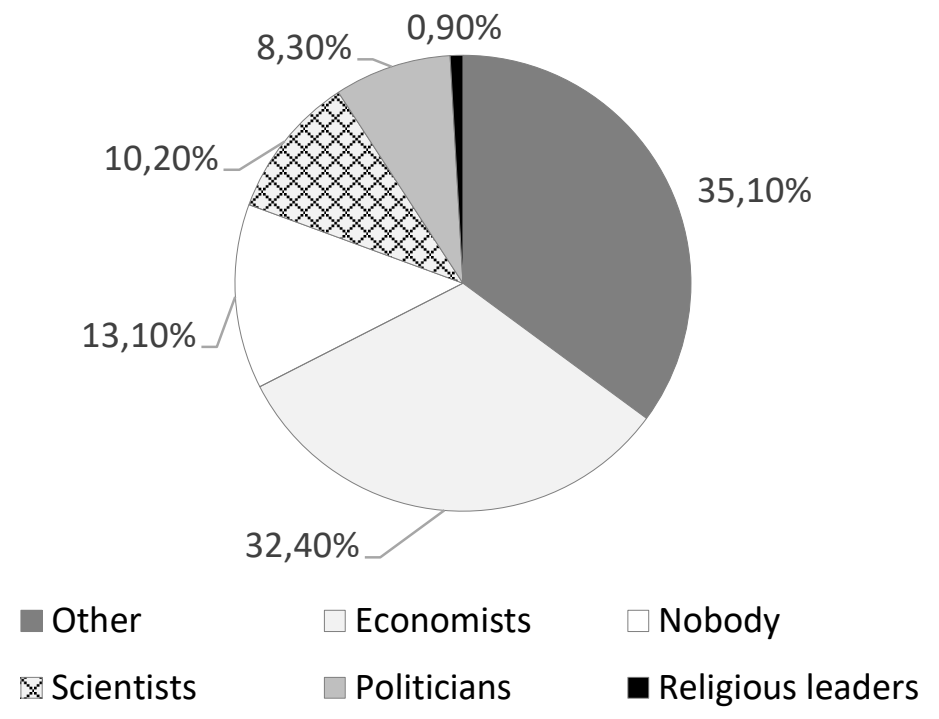

Figure 2 Groups preferred for solving global problems Source: Lengyel 2015

Another typical driving force behind the mechanism of involuntary denial is the maintenance and protection of the self-image, generally a self-image that is valued by society. [20] Examined a large sample $(n=2785)$ covering five countries and found that the majority of respondents denied any responsibility for choosing a non-sustainable trip and /or destination. Even the $19 \%$ of the sample, which would otherwise show the greatest openness to sustainability, found an excuse.

\subsection{Power of habit}

Fixed habits play a huge role in the majority of people not moving towards a more sustainable way of life [15]. Verhoeven et al. describes habits in the following way, „Habits are performed in a stable context, as a response to a particular situation or external cue. In addition, and arguably most importantly, habits are performed automatically. The notion that habits are automatic entails that they are performed efficiently, effortlessly, unconsciously, unintentionally, and with little controllability and precisely these characteristics make habits hard to change when they become unwanted" [42:760].

Verplanken mentions three pillars of habits regarding sustainability. These are: repetition, automation, external control [43]. Repetition, in relation to sustainability, is a significant negative aspect of habit, as it is exactly how harmful effect on the environment and on humans cumulates over time. Examples include car use or snacking. In some situations, automation may seem to be an efficient process for resources (for example, performing multiple tasks at the same time), however, sometimes negative effects are much more pronounced. Take the typical habit of watching television while eating. In the depth of the seemingly time-efficient solution we can see that the food consumed in this way may cause digestive problems and the information you hear with the 'half-ear' may sink into the unconscious. The latter is good news for the consumer propaganda machine as it is much easier to manipulate consumers through their subconscious forces [3]. Since habitual actions are automatically triggered by certain contextual stimuli, control over the action is moved from the individual to the outside environment. This is closely related to the above-mentioned aspect of automation and provides an easy "point of attack" for the consumer machinery [8]. The abovementioned aspects of habit are closely related to mental processes and negative mental habits [11]. One of the main reasons for adhering to habits is the fear of change; familiar things have a great inertia [25]. Psychological phenomena called "change inertia" or "status quo bias" in the literature affects the willingness to change the usual system [13]. 


\subsection{Cry wolf effect}

The phenomenon has been known since Aesop. In the story shepherd boy cries wolf too often with no reason making people disbelieve him when the wolf really appears. In the English-language literature, evidence for the 'cry wolf' or 'false alarm' hypothesis has been found in several studies including areas such as earthquake predictions [2] or oil depletion [32]. The frequently prophesized but ultimately not materializing catastrophes give the false illusion that this will always be the case, however, with the present socio-ecological crisis it is not the case. In fact, the 'false alarm' effect is a "trust deficit" [4] and the apathy that results from it [26].

\subsection{Possession}

It is the central dogma of the consumer religion which commands: Get it and you will be happy. Even if we accept the opinion of critics of the Easterlin paradox [10] that economic growth and hedonic subjective well-being are significantly and positively correlated and no ceiling can be identified [41], the level of happiness or subjective well-being cannot be raised in the long term in this way as the growth paradigm based on consumption and economic growth is unsustainable [33, 44]. Some authors claim that the loss of leisure time caused by the 'treadmill effects' and the resulting erosion of relationships and in turn [23] the decreasing social integrity and solidarity [21] might lead to a decrease in even the level of hedonic wellbeing [27].

Those who have internal (spiritual) development as their primary (intrinsic) goal are characterized by significantly higher subjective well-being than those who are primarily driven by extrinsic or material goals. [22, 31]. Van Boven (2005) conducted a nationwide survey and found that materialism-driven aspirations are in the path of wellbeing. The more someone is driven by materialistic goals the less satisfied they are with life and the greater the risk of psychiatric illnesses occurring. According to [24], materialistic value orientation is formed by two fundamental processes in the individual's psychological development. One is the compensation for the feeling of uncertainty stemming from the negative effects arriving from the narrower (family, community) and wider (society) psychological environment. The other is the internalization of the values of the same environments during socialization. Materialistic goals are negatively correlated with empathic and cooperative behaviour and positively with manipulative and competing attitude.

\subsection{Technological optimism or waiting for the miracle}

Let us start with a thought experiment. Suppose that by 2050 every industry uses zeroGHG technology. Will consumption decrease? Will there be fewer people with psychological problems in the increasingly crowded urbanized spaces? Will the distribution of goods be fairer? Will we spend most of our energies on internal growth?

Many parallels can be drawn between the behaviour of individuals and communities in crisis situations. As individuals prefer pills rather than lifestyle changes in consumer societies, the illusion that science and technology ("pills") will solve all sustainability issues and we can go on without sacrifices, business as usual.

Hoping for the "techno-fix" [18] is a collective procrastination of solving the deeper problem. It is all about transformation. As with individual transformation, which is in some sense death and rebirth, in scientific terminology, a paradigm shifts and the resulting behavioural change work in the same way for society. Scientific-technical progress is important, but it is far from being enough [16]. An increase in efficiency (e.g. energy efficiency) does not automatically lead to a reduction in consumption. Originally observed by Jevons, an English economist in the 19th century, it is called rebound effect but is also known as KhazoomBrooks effect. The essence of this is that technical innovations for energy efficiency do not necessarily lead to a reduction in the proportional use of resources, as consumer habits do not change so easily. The Jevons paradox has a wide range of empirical and theoretical literature [14]. The size of the effect is a point of argument, but there is a broad consensus that it should be calculated in climate strategies [40]. 


\section{Conclusions}

The goal of the present study was to call attention to psychological and social mechanism that lie behind decades of failure to manage the sustainability challenge. In many ways this challenge might be the biggest humanity has ever had to face. The above described, not easily controllable, often subconscious mechanisms, and several others not mentioned in this paper for lack of space, are the biggest hindrances to effective action. Are we on an unchangeable collision course already? Can action be meaningful at all or is it too late? Even if it was scientifically verified that a catastrophe is unavoidable, which is not the case at the moment, our mission as sentient, reasonable, ethical and spiritual beings on Earth is still to do the right thing up to the last moment of our life here. This attitude is encouraged by all big religions of the world. We might even be optimistic and hope that if we are able to change our world view and lifestyle considerably, it could be enough help for the ecosystem to cure itself. It is a big change regarding the quality of our life. From materialistic values to mostly eudemonic ones. As in quality management, leaders, that is, decision makers of all levels should set a strong and clear example for their communities.

\section{Acknowledgements}

This research is supported by EFOP-3.6.1-16-2016-00006 "The development and enhancement of the research potential at John von Neumann University" project. The Project is supported by the Hungarian Government and co-financed by the European Social Fund.

\section{References}

[1] Ackerman, D. S.-Gross, B. L.-Sawhney Celly, K. (2014): Having many choice options seems like a great idea, but... Student perceptions about the level of choice for a project topic in a marketing course. Journal of Marketing Education, 36(3) p. 221-232.

[2] Atwood, L. E.-Major, A. M. (1998): Exploring the 'cry wolf' hypothesis. International Journal of Mass Emergencies and Disasters, 16(3) p. 279-302.

[3] Boulos, R.-Vikre, E. K.-Oppenheimer, S.-Chang, H.-Kanarek, R. B. (2012): ObesiTV: how television is influencing the obesity epidemic. Physiology \& behavior, 107(1) p. 146-153.

[4] Breznitz, S. (2013): Cry wolf: The psychology of false alarms. Psychology Press.

[5] Chen, Y.-Kang, Y.-Gong, W.-He, L.-Jin, Y.-Zhu, X.-Yao, Y. (2016): Investigation on Internet addiction disorder in adolescents in Anhui, People's Republic of China. Neuropsychiatric Disease and Treatment, 12, 2233-2236.

[6] Cramer, P. (2006): Protecting the self: Defense mechanisms in action. Guilford Press.

[7] Diamond, J. (2005): Collapse: How societies choose to fail or succeed. Penguin.

[8] Duhigg, C. (2013): The Power of Habit: Why we do what we do and how to change. Random House.

[9] Dunlap, R. E.-Mccright, A. M. (2011): Organized climate change denial. The Oxford handbook of climate change and society, p. 144-160.

[10] Easterlin, R. A. (2015): Happiness and economic growth-the evidence. In Global handbook of quality of life. p. 283-299. Springer Netherlands.

[11] Epstein, R. M. (2003): Mindful practice in action (II): Cultivating habits of mind. Families, Systems, \& Health, 21(1) p. 11-17.

[12] Festinger, L. (1962): A theory of cognitive dissonance (Vol. 2). Stanford university press.

[13] Feygina, I.-Jost, J. T.-Goldsmith, R. E. (2010): System justification, the denial of global warming, and the possibility of "system-sanctioned change". Personality and Social Psychology Bulletin, 36(3) p. 326-338.

[14] Freire-González, J. (2017): Evidence of direct and indirect rebound effect in households in EU-27 countries. Energy Policy, 102, p. 270-276.

[15] Gifford, R. (2011): The dragons of inaction: psychological barriers that limit climate change mitigation and adaptation. American Psychologist, 66(4) p. 290.

[16] Gunderson, R.-Stuart, D.-Petersen, B. (2017): Ideological obstacles to effective climate policy: The greening of markets, technology, and growth. Capital \& Class. 1, p. 1.27.

[17] Hemp, P. (2009): Death by information overload. Harvard business review, 87(9) 83-89.

[18] Huesemann, M.-Huesemann, J. (2011): Techno-fix: why technology won't save us or the environment. New Society Publishers.

[19] Iyengar, S. S.-Lepper, M. R. (2000): When choice is demotivating: can one desire too much of a good thing? Journal of Personality and Social Psychology, 79(6) p. 995-1006.

[20] Juvan, E.-Ring, A.-Leisch, F.-Dolnicar, S. (2016): Tourist segments' justifications for behaving in an environmentally unsustainable way. Journal of Sustainable Tourism, 24(11) p. 1506-1522.

[21] Kasser, T. (2002): Sketches for a self-determination theory of values. In E. L. Deci \& R. M. Ryan (Eds.), Handbook of self-determination research. p. 123-140. Rochester, NY: University of Rochester Press. 
[22] Kasser, T.-Rosenblum, K. L.-Sameroff, A. J.-Deci, E. L.-Niemiec, C. P. -Ryan, R. M.-Hawks, S. (2014): Changes in materialism, changes in psychological well-being: Evidence from three longitudinal studies and an intervention experiment. Motivation and Emotion, 38(1) p. 1-22.

[23] Kasser, T.-Ryan, R. M. (2001): Be careful what you wish for: Optimal functioning and the relative attainment of intrinsic and extrinsic goals. In P. Schmuck \& K. M. Sheldon (Eds.), Life goals and well-being: Towards a positive psychology of human striving. p. 116-131. Goettingen, Germany: Hogrefe \& Huber.

[24] Kasser, T.-Ryan, R. M.-Couchman, C. E.-Sheldon, K. M. (2004): Materialistic values: Their causes and consequences. Psychology and consumer culture: The struggle for a good life in a materialistic world, p. 1128.

[25] Kuppens, P.-Allen, N. B.-Sheeber, L. B. (2010): Emotional inertia and psychological maladjustment. Psychological Science, 21(7) p. 984-991.

[26] Ladle, R. J.-Jepson, P.-Whittaker, R. J. (2005): Scientists and the media: the struggle for legitimacy in climate change and conservation science. Interdisciplinary Science Reviews, 30(3) p. 231-240.

[27] Lane, R. E. (2000): Diminishing returns to income, companionship-and happiness. Journal of Happiness Studies, 1(1) p. 103-119.

[28] Lányi, A. (2013): Morális klímaváltozás. Magyar tudomány. 7, p. 822-829.

[29] Lengyel, A. (2015): Fenntarthatóság: megoldási alternatívák. Kutatói esszé. SZIE RTDI.

[30] Lorenzoni, I.-Nicholson-Cole, S.-Whitmarsh, L. (2007): Barriers perceived to engaging with climate change among the UK public and their policy implications. Global environmental change, 17(3) p. 445-459.

[31] Martos, T. (2010): Élet célok és Lelki Egészség a Magyar Társadalomban Doktori (PhD) Értekezés Semmelweis Egyetem Mentális Egészségtudományok Doktori Iskola

[32] [32] Maugeri, L. (2004): Oil: never cry wolf--why the petroleum age is far from over. Science, 304(5674) p. 1114-1115.

[33] Meadows, D. H.-Meadows, D. (2007): The history and conclusions of The Limits to Growth. System Dynamics Review, 23(2-3) p. 191-197.

[34] Meier, R. L. (1962): A communications theory of urban growth. Published for the Joint Center for Urban Studies of the Massachusetts Institute of Technology and Harvard University by MIT Press.

[35] Milbrath, L. W. (1995): Psychological, cultural, and informational barriers to sustainability. Journal of Social Issues, 51(4) p. 101-120.

[36] Misra, S.-Stokols, D. (2012): Psychological and health outcomes of perceived information overload. Environment and Behavior, 6., p. 737-759

[37] Ripple, W. J., Wolf, C., Newsome, T. M., Galetti, M., Alamgir, M., Crist, E., ... \& 15,364 scientist signatories from 184 countries. (2017). World scientists' warning to humanity: a second notice. BioScience, 67(12), 1026-1028.

[38] Shi, J.-Visschers, V. H.-Siegrist, M.-Arvai, J. (2016): Knowledge as a driver of public perceptions about climate change reassessed. Nature Climate Change, 6(8) p. 759-762.

[39] Vaillant, G. E. (2000): Adaptive mental mechanisms: Their role in a positive psychology. American psychologist, 55(1) p. 89.

[40] van den Bergh, J. C. (2016): Rebound policy in the Paris agreement: Instrument comparison and climateclub revenue offsets. Climate Policy, 17, p. 1-13.

[41] Veenhoven, R.-Vergunst, F. (2014): The Easterlin illusion: economic growth does go with greater happiness. International Journal of Happiness and Development, 1(4) p. 311-343.

[42] Verhoeven, A. A.-Adriaanse, M. A.-Evers, C.-DE Ridder, D. T. (2012): The power of habits: Unhealthy snacking behaviour is primarily predicted by habit strength. British journal of health psychology, 17(4) p. 758-770.

[43] Verplanken, B. (2010): Habit: from overt action to mental events. in Christopher R. A.-Donal E. C.-William G. G.-Janice R. K. (Eds.) p. 68-88. Then a miracle occurs: Focusing on behavior in social psychological theory and research. Oxford Scholarship Online

[44] Zsolnai, L. (Ed.). (2011): Ethical Principles and Economic Transformation-A Buddhist Approach (Vol. 33). Springer Science \& Business Media. 